\title{
Genesis of the high gamma sandstone of the Yanchang Formation in the Ordos Basin, China: A reply
}

\author{
Zhang Xiaoli'*, Feng Qiao², Feng Qianghan², Liu Jingjing ${ }^{3}$, Liu Guangwei ${ }^{1}$ \\ and Yan Yuanzi ${ }^{1}$ \\ ${ }^{1}$ State Key Laboratory of Continental Dynamics/Department of Geology, Northwest University, Xi'an, Shaanxi 710069, \\ China \\ ${ }^{2}$ College of Geological Science \& Engineering, Shandong University of Science and Technology, Qingdao, Shandong \\ 266510, China \\ ${ }^{3}$ State Key Laboratory for Exploration and Development of Low-permeability Oil and Gas Fields, Oil \& Gas Technology \\ Research Institute, Changqing Oilfield Company, PetroChina, Xi'an, Shaanxi 710018, China
}

(C) China University of Petroleum (Beijing) and Springer-Verlag Berlin Heidelberg 2013

\begin{abstract}
The authors of 'Genesis of the high gamma sandstone of the Yanchang Formation in the Ordos Basin, China' questioned the viewpoint that high-gamma-ray sandstone might be caused by homochronous sedimentary volcano tuff ash or previous tuff. The authors argued that the main reason for the high-gamma-ray sandstone should be from high Th and U contents in zircon. In reply, we discuss the problems with the authors from the category of high-gamma-ray sandstones, rock characteristics, and possible sources of radioactivity. The results still indicate that the high gamma ray characteristics might be caused by homochronous sedimentary volcano tuff ash or reworked previous tuffs.
\end{abstract}

Key words: High-gamma-ray sandstone, provenance, event deposit, Yanchang Formation, Ordos Basin

\section{High-gamma-ray sandstone category}

High-gamma-ray sandstone refers to sandstone with low mud content but with higher gamma ray than normal, that is, those sandstones where the high-gamma-ray is not caused by mud content (Zhang et al, 2010). According to the characteristics of logging curves and the core analysis of Fig. 1 in Liu's paper (Liu et al, 2013), the well section from 1,889 to $1,893 \mathrm{~m}$ in well y91 is a conventional sandstone. However, the gamma ray count increases significantly in the underlying $5 \mathrm{~m}$, from 1,893 to $1,898 \mathrm{~m}$. The high-gamma-ray sandstone between 1,893 and 1,898 $\mathrm{m}$ may be due to an increased content of clay minerals such as chlorite, reticulate clay minerals and mildly radioactive minerals such as muscovite. The reasons are as follows:

1) Compared with the well section from 1,889 to 1,893 $\mathrm{m}$ in well $\mathrm{y} 91$, the logging curve characteristics of the well section from 1,893 to $1,898 \mathrm{~m}$ are higher gamma ray value, smaller spontaneous potential amplitude, higher compensated neutron $\log$ value, lower density, higher AC (acoustic logging) value, and smaller amplitude between dual induction curves and focused resistivity curves. It is inferred that the

*Corresponding author. email: xiaoli_nwu@163.com Received September 10, 2012 logging characteristics changes in the well section from 1,893 to $1,898 \mathrm{~m}$ may be derived from the increase of clay mineral content and radioactive mineral content. Because Table 2 in Liu's paper (2013) did not provide detailed core thin section data, only the thin section data in $1,894.27,1,895.31$ and $1,895.65 \mathrm{~m}$, it can be found that the muscovite content is high in lithic fragments, and the chlorite, reticulate clay (includes montmorillonite and mixed layer illite/smectite) and mica contents are high in interstitial material.

2) The core thin section analysis of high-gamma-ray sandstone from 1,893 to $1,898 \mathrm{~m}$ in well y91 shows that the compositions of the sandstone are quartz and feldspar, and their contents are $22 \%-28 \%$ and $40 \%-46 \%$ respectively. Lithic fragments are mainly mica, phyllite and dolomite and the interstitial materials are mainly chlorite and reticulate clay. Then, how many types of feldspar are there and what are their proportions?

3) Liu's paper (2013) did not provide gamma results separately for $\mathrm{U}$, Th and $\mathrm{K}$ in core from well sections 1,893$1,898 \mathrm{~m}$ and 1,889-1,893 $\mathrm{m}$ in well y91, so we do not know if the radioactive source of high-gamma-ray sandstone in well section $1,893-1,898 \mathrm{~m}$ is mainly $\mathrm{U}$, Th or $\mathrm{K}$ or a mixture of all. Hence one cannot conclude definitely that the radioactive source of high-gamma-ray sandstone was the high content of Th and $U$ in zircon.

Therefore, we suggested that the radioactive source 
of high-gamma-ray sandstone should be derived from the increase of clay and mildly radioactive mineral contents.

\section{High-gamma-ray sandstone petrology}

Liu's paper (2013) mentioned that although Chang 7, Chang 8 and Chang 9, which might be eroded and transported by later water, redeposited and provided material for Chang 6 , have relatively high Th content, the Th content did not increase in Chang 6 (only 5-15 ppm). Therefore, the highgamma-ray sandstones might be related to a gravity flow event deposit and have specific sedimentary background. Generally, tuff has a higher Th content and it is one of the high-gamma-ray sandstone compositions of Chang 6 . The content of element Th in tuffs would not be the same as that in Chang 6, Chang 7, Chang 8 and Chang 9 where tuffs were transported and redeposited. Tuff would be altered in the late diagenetic evolution and its alteration products were mainly clay minerals such as montmorillonite, illite, mixed layer illite/smectite, and chlorite (Qiu et al, 2010). It is common to find montmorillonite and illite, mixed layer illite/smectite and secondary chlorite in high-gamma-ray sandstones. However, tuffaceous debris or tuff fillings are rarely found. Zuo et al (2008) regarded that the volcanic beds including andesite, rhyolitic welded tuff and glassy tuff, occurred as volcanic debris in sandstones or in the thin tuff beds, particularly in Chang 7, Chang 6 and Chang 4+5 members during the initial and stable depression stages. Zuo et al (2008) also showed the variation of volcanic tuff and their contents in oil beds of the Yanchang Formation.

\subsection{Feldspar content}

Examination of Chang $4+5$ and Chang 6 sandstone cores reveals that potassium feldspar is common in the southeast of the Ordos Basin. This has been verified by many authors (Fu et al, 2010; Liang et al, 2008; Lin and Yao, 2000; Yang et al, 2010; Zhao et al, 2008a; 2008b). Thin sections of Chang 6 sandstones in the Chuan 46 area, Chuankou Oilfield in the Ordos Basin, show that the feldspar content ranges from $31 \%$ to $69 \%$. In the $30 \%$ of all samples, the content of feldspar is greater than $55 \%$. The analysis also shows that K-feldspar content ranges from $20 \%$ to $55 \%$, and $\mathrm{K}$-feldspar is greater than $40 \%$ in the $27 \%$ of all samples. The comparison between the thin section data and the responses of logging curves reveals that when the thin section shows the sandstones have a high K-feldspar content, the gamma-ray log presents obviously high values, which means that the high radioactive characteristics might come from K-feldspar. The data in Fig. 1 of Zhang et al (2010) was from middle and west part of oilfield in the Ordos Basin. There were almost no highgamma-ray sandstone samples of Chang 6 from southeast area except one sample from the Ansai Oilfield.

\subsection{Clay}

Fig. 1 shows the relationship between gamma ray and clay contents of sandstones in the Ordos Basin which can also be seen in Fig. 1 in Zhang et al (2010). By comparison, Fig. 1 used both conventional sandstone samples and high-gammaray sandstone samples. Zhang et al (2010) defined that when the gamma-ray value is greater than 85API, the sandstones of the Chang 2 and Chang 6 formations in the Dingbian, Wuqi and Zhidan Oilfields are high-gamma-ray sandstones. In Fig. 1, we may find that the sandstone radioactivity may be a positive correlation with the content of clay minerals when the gamma ray value is greater than 85API. Furthermore, $\mathrm{X}$-ray diffraction and corresponding well logging analysis shows that the content of illite, mixed layer illite/smectite and kaolinite in sandstones increased with gamma-ray values in sandstones.

While the relationship between the chlorite content and the gamma ray value is not obvious. Overall, the highgamma-ray sandstones have high contents of illite, kaolinite and mixed layer illite/smectite. Their correlation is positive. For these reasons, the argument of Liu et al (2013) that the relationship between the gamma ray and the mineral content is not positive does not meet the information from Fig. 1 (Zhang et al, 2010).
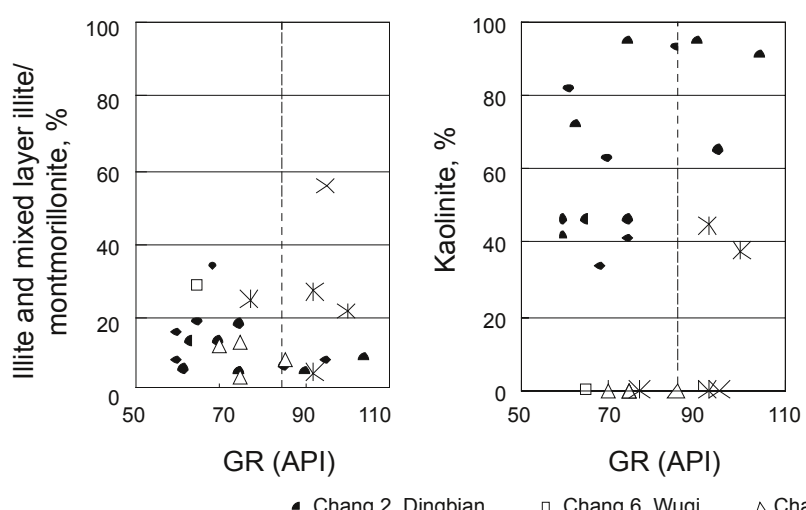

- Chang 2, Dingbian

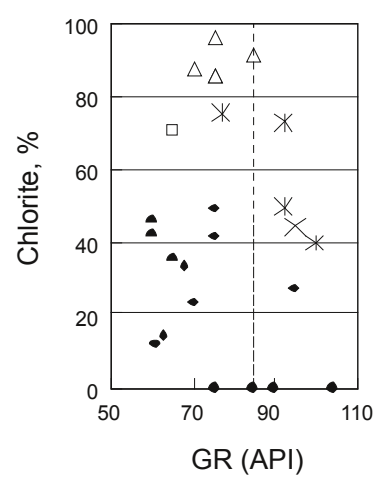

* Chang 6, Zhidan

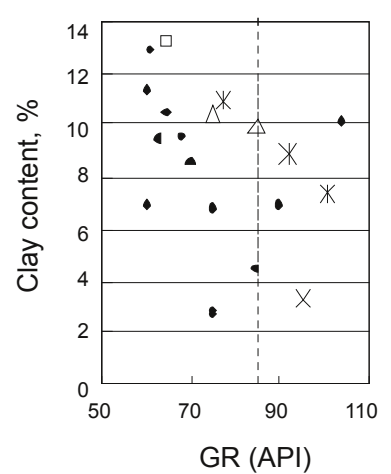

$\times$ Chang 2 , Zhidan

Fig. 1 Relationship between gamma ray and clay contents in the Ordos Basin

\subsection{Heavy minerals}

Liu et al (2013) analyzed the Yanchang Formation provenance characteristics and zircon content characteristics in heavy minerals in detail. They thought that the high gamma values are due to the $U$ and $T h$ in zircon. If the provenance heterogeneity results in local high gamma ray 
sandstone, it is likely. Then, the distribution of high-gammaray sandstone should be along the flow direction and fill in channel and branch channel. However, the compositions of the material source in different delta sand bodies are quite different in Chang 6 and Chang $4+5$ deposition periods in the Ordos Basin (Song et al, 2002; Yang, 2005). Furthermore, it is suggested that the causes of the high-gamma-ray sandstone might not be related to source, because different sand bodies had the same high-gamma-ray features in the same deposition period. According to data from oil areas of Ordos Basin, highgamma-ray sandstones in Chang 2, Chang 4+5 and Chang 6 formations do not spread along the flow direction of channel.

\section{Discussion}

Liu et al (2013) concluded that it is probably caused by magmatic origin that high-gamma-ray in sandstones of Yanchang Formation might come from high Th and $\mathrm{U}$ contents in zircon. Radioactivity determination and gammaray spectrum logging of high radioactive sandstones reveal that high-gamma-ray sandstone characteristics have high Th and locally high U contents ( $\mathrm{Li}$ et al, 2006; Qiu et al, 2009; Sun et al, 2010). Even if the radioactive element characteristics indicate high radioactivity may be associated with zircon, but may not be an entirely genetic relationship with source rocks. Because the excessive volcanic eruption events had occurred in the deposition process of Yanchang Formation in the Ordos Basin, the resulting ash can contribute to the high radioactivity, and may even be the main contribution. According to Qiu et al (2010), the volcanic ash was widely distributed, and they thought that the tuff had layered development. But the degree of development about the tuff crumbs or tuffaceous interstitial material in sandstones was not discussed. In addition, Zuo et al (2008) clearly described that the volcanic clastics and volcanic ash was developed in the Yanchang Formation, and their contents were from $3 \%$ to $6 \%$. The deposition way of volcanic material may be the suspended drift and river carrying. This view implies the high-gamma-ray sandstone may have local distribution.

\section{References}

Fu G M, Zhao J X, Zhang Z S, et al. The provenance and features of depositional system in the Yanchang Formation of Triassic in southeast area of Ordos Basin. Journal of Mineralogy and Petrology. 2010. 30(1): 99-105 (in Chinese)
Li G R, Guo Q Y, Shi Y J, et al. Identification of high gamma ray reservoir in Ordos Basin. Well Logging Technology. 2006. 30(6): 511515 (in Chinese)

Liang J W, Xiao L, Gao X L, et al. Source analysis during the early Late Triassic in Ordos Basin. Northwestern Geology. 2008. 4(2): 81-86 (in Chinese)

Lin H B and Yao J L. Depositional feature and material source analysis of Yanchang Group in Ordos Basin. Journal of Xi'an Petroleum Institute. 2000. 15(5): 7-9 (in Chinese)

Liu H Q, Li X B, Liao J B, et al. Genesis of the high gamma sandstone of the Yanchang Formation in the Ordos Basin, China. Petroleum Science. 2013. 10(1): 50-54

Qiu X W, Liu C Y, Li Y H, et al. Distribution characteristics and geological significances of tuff interlayers in Yanchang Formation of Ordos Basin. Acta Sedimentologica Sinica. 2009. 27(6): 1138-1146 (in Chinese)

Qiu X W, Liu C Y, Mao G Z, et al. Enrichment feature of thorium element in tuff interlayers of Upper Triassic Yanchang Formation in Ordos Basin, China. Geological Bulletin of China. 2010. 29(8): 1185-1191 (in Chinese)

Song K, Lü J W, Du J L, et al. Source direction analysis and delta depositional systems of Yanchang Formation of the Upper Triassic in the central Ordos Basin. Journal of Palaeogeography. 2002. 4(3): 5966 (in Chinese)

Sun P, Zhang X L, Guo L, et al. Genesis of the sandstone with higher radioactivity and the qualitative evaluation of its reservoir property: Taking Chang 6 oil-bearing strata in Zhidan Oilfield, Ordos Basin as an example. Journal of Xi' an Shiyou University (Natural Science Edition). 2010. 25(2): 18-21 (in Chinese)

Yang H. Deposition system and oil accumulation research of Yanchang Formation in Triassic, Ordos Basin. Ph.D. Thesis. Chengdu University of Technology. 2005 (in Chinese)

Yang H, Dou W T, Liu X Y, et al. Analysis on sedimentary facies of member 7 in Yanchang Formation of Triassic in Ordos Basin. Acta Sedimentologica Sinica. 2010. 28(2): 254-263 (in Chinese)

Zhang X L, Feng Q, Sun P, et al. Characteristics of high-gammaray sandstone reservoirs for Yanchang Formation in Ordos Basin. Chinese Journal of Geophysics. 2010. 53(1): 154-163

Zhao J X, Chen H D, Fu S T, et al. Discussion on some important depositional events and their relationship with hydrocarbon accumulation of Yanchang Formation in south Ordos Basin. Journal of Mineralogy and Petrology. 2008a. 28(3): 90-95 (in Chinese)

Zhao J X, Lü Q, Li F J, et al. Sediment provenance analysis of the Chang 6 oil-bearing of Yanchang Formation in the south of Ordos Basin. Acta Sedimentologica Sinica. 2008b. 26(4): 610-616 (in Chinese)

Zuo Z F, Qi Y, Ge X R, et al. Effect of late Triassic volcanic sediment event on hydrocarbon accumulation conditions in Ordos Basin. Journal of Lanzhou University (Natural Sciences). 2008. 44(3): 1215 (in Chinese) 